\title{
Repercussions of Smoking Habit on Orofacial Pain and Temporo- mandibular Dysfunction: Integrative Review
}

\author{
Oliveira-Souza AIS ${ }^{*}$, Oliveira Ferro $J^{1}$, Santana da Silva $T^{2}$, Vasconcelos SC', Costa Lima, MD', \\ and Oliveira $D A^{3}$
}

\begin{abstract}
${ }^{1}$ PhD Student, Neuropsychiatry and Behavioral Sciences Program, Federal University of Pernambuco-UFPE, Brazil
${ }^{2} P h D$, Neuropsychiatry and Behavioral Sciences Program, Federal University of Pernambuco-UFPE, Brazil

${ }^{3}$ PhD, Adjunct Professor, Department of Physical Therapy, Federal University of Pernambuco-UFPE, Brazil

*Corresponding author: Oliveira-Souza AIS, PhD Student, Department of Biomechanics, Federal University of Pernambuco, Francisco da Cunha street, number: 1325, Apto: 403, Boa Viagem, Pernambuco, CEP: 51020-041, Brazil, Tel: (81)-981421230
\end{abstract}

\begin{abstract}
Temporomandibular dysfunction (TMD) can be triggered by several factors, such as parafunctional habits, among them: smoking. However, the relationship between these two conditions is unclear. The aim of this study was to describe the repercussions of smoke habits in patients with TMD. This is an integrating review with a guiding question considered Population, Intervention, Comparison and Outcomes (PICO). The search strategy was conducted following some Preferred Reporting Items for Systematic Reviews and Meta-Analyses and the methodological quality analysis of the studies was carried out according to New Castle Otawa for cross-sectional studies. The databases: Cumulative Index to Nursing and Allied Health Literature, Medline via Pubmed, Web of Science and Scopus. The risk of bias in the analysis, extraction and inclusion of the manuscripts was reduced by independent peer evaluation. In conclusion smoking is able to negatively affect the pain perception of patients with TMD, besides influencing comorbid aspects such as fatigue, pain control, sleep quality and psychological distress. Moreover, it is not possible to consider that there is an association between worsening of pain intensity and biomechanical aspects of smoking because of the scarcity of good evidence.
\end{abstract}

\section{Keywords}

Smoking, Tobacco, Facial Pain, Temporomandibular Joint Dysfunction Syndrome

\section{Introduction}

Temporomandibular dysfunction (TMD) is one of the most common causes of orofacial pain, affecting ap- proximately $10-15 \%$ of the population [1]. TMD is associated with the presence of pain in the preauricular region, muscular fatigue of the masticatory muscles, limitation or deviations during jaw movement and may be associated with noises during opening and closing of the mouth [2,3]. The prognostic factors related to the development of TMD are still very imprecise and studied. Previous studies have shown that this population has higher levels of distress, catastrophic feelings and increased somatic awareness compared to healthy controls.

TMD has been associated with other conditions of psychological and chronic pain, including fibromyalgia, back pain, headaches, and chronic generalized pain [4-6]. One of the major dysfunctions of muscle tissue affecting TMD patients is myalgia. The two primary precipitating factors associated with TMD-related myalgia are the formation of symptomatic myofascial trigger points and parafunctional habits $[2,3,5,7]$, including smoking habit.

The investigation of smoking in patients with TMD is very important, not only because of the direct negative potential of cigarette smoke, but also because smoking habit may be related to the effects of other TMD risk factors, including perceived stress, anxiety, and depression $[8,9]$. It is known that tobacco smoke plays an important negative role in various types of chronic pain, 
as it was found that the greater exposure to tobacco the bigger risk of presenting pain [9].

The active ingredients in tobacco smoke that alter the perception of pain are not fully understood, but it is generally assumed that nicotine is the main substance that modifies the perception of pain. The effects of nicotine on pain perception are complex $[10,11]$. Experimental studies that use brief noxious stimuli after nicotine intake provide evidence that nicotine has analgesic properties. Chronic exposure to tobacco leads to changes in pain perception, so smokers deprived of nicotine show increased sensitivity to pain evoked stimuli. Chronic exposure to nicotine may induce biological states that produce hyperalgesia and dependence similar to that observed with chronic exposure to opioids when nicotine levels are reduced sharply [9].

Previous studies have shown that in patients with TMD, smoking increased the intensity of crises. And there was carry evidence that pain intensity increased as daily cigarette consumption also increased [8]. However, no study can elucidate a cause and effect relationship between smoking, temporomandibular dysfunction, and orofacial pain, or even elucidate whether there is a strong link between the severity of the pain crises and the smoking habit.

Therefore, the objective of the present integrative review was to describe the repercussions of smoking habit in patients with temporomandibular dysfunction.

\section{Materials and Methods}

It was decided to carry out an integrative review of the literature [11], that it is known for broadly addressing the topic it is proposed to discuss. The present study was divided into two phases. The first phase consisted in the creation of the search strategy, which was based on the guiding question: "Does smoking influence the intensity/prevalence of orofacial pain in patients with TMD?", led by the PICO strategy, which represents the acronym for Patient, Intervention, Comparison and Outcomes [12]. While in the second phase the data extraction and evaluation of the methodological quality of the complete articles were carried out.

In spite of being an integrative review, the authors opted for the criteria according to the model of the Preferred Reporting Items for Systemic Reviews and Meta-Analysis (PRISMA), using the flowchart that shows
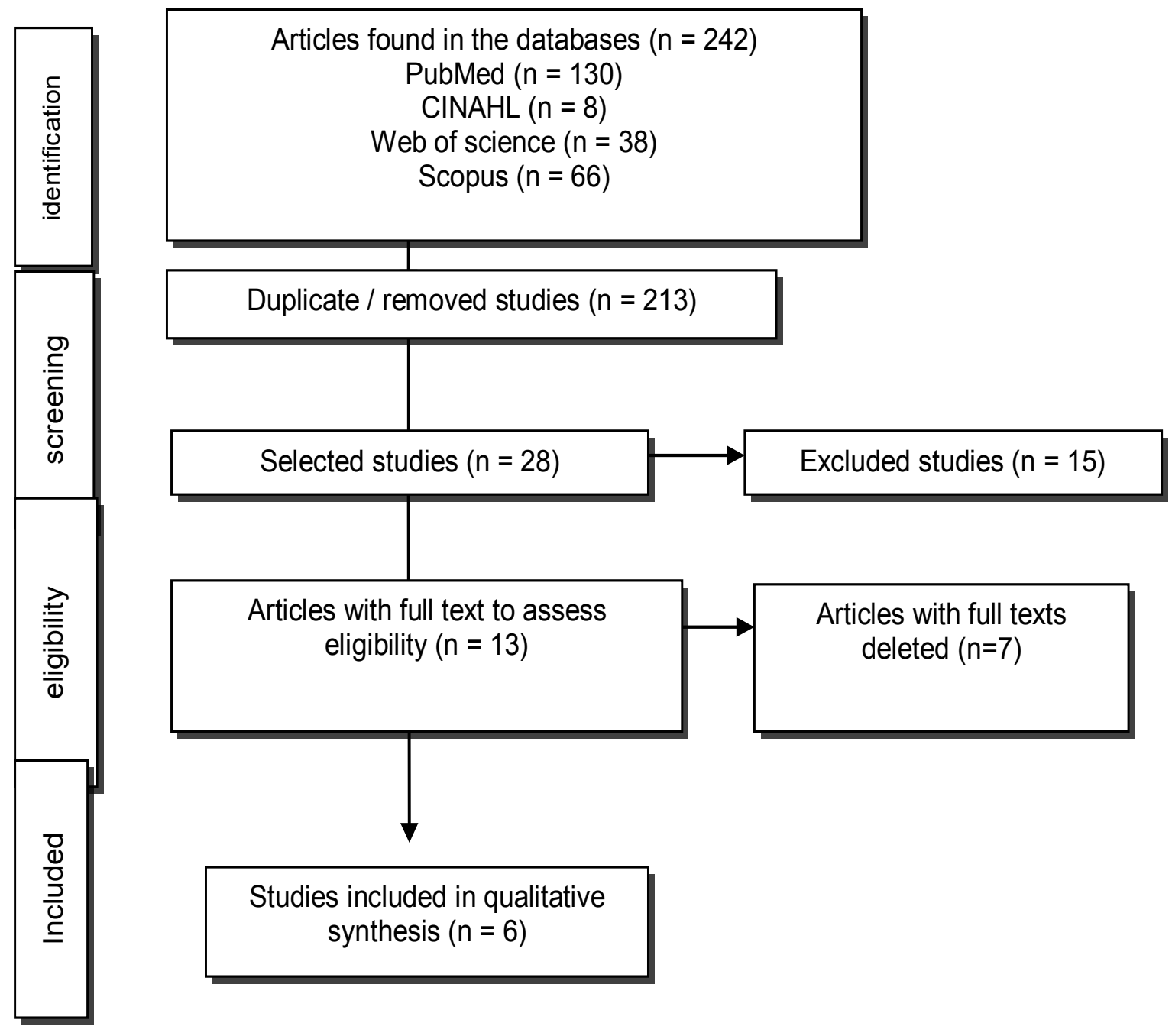

Figure 1: Flowchart and criteria for selection and inclusion of articles. 
in detail the process of selection of the articles (Figure 1) [13].

Observational studies (cross-sectional, cohort, case-control and case series) were searched in the following databases: Cumulative Index to Nursing and Allied Health Literature (CINAHL), Medline via Pubmed, Web of Science and Scopus via Coordination for the Improvement of Higher Education Personnel (CAPES). We used articles with no temporal and linguistic restriction, using the descriptors registered in the Medical Subject Headings (mesh): "Smoking", "Tobacco", "Orofacial Pain"; combined with the Boolean operator: AND "and" OR.

Inclusion criteria were observational studies that used as a dependent variable important TMD clinical signs and symptoms, such as pain intensity, presence of noise and reduction of jaw range of motion, in adult patients with orofacial pain and temporomandibular dysfunction, and smoking as an independent variable of interest, the diagnosis of temporomandibular dysfunction must have been through the Research Diagnostic Criteria for TMD (DC/TMD). Studies in which the target population was non-smokers or children and adolescents, who discussed dental health in dental settings, such as caries development and tooth loss, were excluded from the analysis.

The searches were carried out between October and November 2017. In an attempt to reduce the risk of bias, all the articles located by the search strategy were analyzed by two independent reviewers, who accessed and identified articles from titles and abstracts, from according to the eligibility criteria and the disagreements were analyzed by a third evaluator through a consensus meeting. In case of doubt the studies were selected for later analysis of the full text.

The evaluation of the methodological quality of the selected studies was done by two independent reviewers using the New Castle - Ottawa quality assessment scale/cross-section studies (NOS). This tool analyzes articles according to: Selection (sample representativeness, sample size, subjects who did not respond, exposure/risk factors), Comparability and Outcomes (evaluation of outcomes, statistical analysis). The qualitative analysis of the NOS is performed using the total classification of 10 stars, distributed in three domains: selection (maximum 5 stars), comparability (maximum two

Table 1: Methodological quality evaluation of included studies according to New Castle - Ottawa quality assessment scale: Casecontrol studies and cross-section studies (NOS).

\begin{tabular}{|c|c|c|c|c|c|}
\hline \multirow{2}{*}{$\begin{array}{l}\text { NOS Evaluation }\left(10^{*}\right) \\
\text { Case-control studies }\end{array}$} & \multicolumn{4}{|c|}{ Included Studies } & \\
\hline & & & & & \\
\hline SELECTION & $\begin{array}{l}\text { Sanders, et } \\
\text { al. [9] }\end{array}$ & & & & \\
\hline Proper case definition & * & & & & \\
\hline Representativeness of cases & * & & & & \\
\hline Selection of controls & * & & & & \\
\hline Definition of controls & & & & & \\
\hline COMPARABILITY & $* *$ & & & & \\
\hline EXHIBITION & & & & & \\
\hline Determination of exposure & * & & & & \\
\hline $\begin{array}{l}\text { Calibration of the verification method } \\
\text { for cases and controls }\end{array}$ & * & & & & \\
\hline Non-responders & - & & & & \\
\hline TOTAL & $7^{*}$ & & & & \\
\hline Cross-sectional studies & & & & & \\
\hline SELECTION & $\begin{array}{l}\text { Burris, et al. } \\
{[18]}\end{array}$ & $\begin{array}{l}\text { Weber, et al. } \\
{[16]}\end{array}$ & $\begin{array}{l}\text { Custodio, et al. } \\
{[15]}\end{array}$ & Melis, et Al. [8] & $\begin{array}{l}\text { Weingarten, et. } \\
\text { al. [10] }\end{array}$ \\
\hline Representativeness & - & - & - & * & * \\
\hline Sample size & - & - & - & - & - \\
\hline Subjects not included in the sample & - & * & * & - & * \\
\hline Exposure Check & ** & ** & ** & * & ** \\
\hline COMPARABILITY & * & * & * & * & * \\
\hline DISCHARGE & & & & & \\
\hline Evaluation of the outcome & * & * & * & * & * \\
\hline Statistical analysis & * & * & * & * & * \\
\hline TOTAL & $5^{*}$ & $6^{*}$ & $6^{*}$ & $5^{*}$ & $7^{*}$ \\
\hline
\end{tabular}

The "*" means the presence of that point is present on the study analyzed, according to NOS scale. 
stars) and outcomes (maximum three stars). The higher number of stars obtained, the better is the study methodological quality.

\section{Results}

We identified 242 articles in the databases searched and after selection and discussion based on title and abstract, 13 references were selected for full reading. Of these, seven articles were excluded because they did not meet the eligibility criteria: one because it was not an observational study, two be- cause they did not relate the smoking habit to orofacial pain, two because they did not use the DC/TMD diagnostic criteria and two, for not having the full text available on any online article search platform and no response was obtained when contacting the authors. Thus, a total of 6 studies were included for the qualitative analysis.

After careful methodological analysis, the included articles presented a quality of moderate evidence. The results can be analyzed in Table 1 . And Table 2 show the

Table 2: Characterization of the articles included in the sample.

\begin{tabular}{|c|c|c|c|c|c|}
\hline $\begin{array}{l}\text { Author/Year/ } \\
\text { Location/Journal/ } \\
\text { Impact Factor }\end{array}$ & $\begin{array}{l}\text { Study } \\
\text { Design }\end{array}$ & Sample & Instruments & $\begin{array}{l}\text { Data } \\
\text { analysis }\end{array}$ & Outcome/Results \\
\hline $\begin{array}{l}\text { Weber et al. 2016/ } \\
\text { United States/ } \\
\text { Journal of Dental } \\
\text { Research/4.755 }\end{array}$ & $\begin{array}{l}\text { Cross- } \\
\text { sectional }\end{array}$ & $\begin{array}{l}610 \text { individuals } \\
\text { aged } 18 \text { to } 80 \text { years, } \\
\text { TMD diagnosis and } \\
\text { history of traumatic } \\
\text { experience. }\end{array}$ & $\begin{array}{l}\text { Diagnosis by DC/TMD; } \\
\text { Visual Analog Scale } \\
100 \text { mm (EVA); } \\
\text { Multidimensional Pain } \\
\text { Inventory (MPI) } \\
\text { Posttraumatic Stress } \\
\text { Disorder Checklist } \\
\text { - Civilian Version } \\
\text { (PCL-C); } \\
\text { Global Severity Index } \\
\text { (GSI) of the Symptom } \\
\text { Checklist-90R (SCL- } \\
\text { 90R); }\end{array}$ & $\begin{array}{l}\text { Test T for } \\
\text { independent } \\
\text { samples; } \\
\text { Chi-square; } \\
\text { Linear } \\
\text { Regression; }\end{array}$ & $\begin{array}{l}\text { Smokers significantly } \\
\text { increased pain }(p<0.001) \text {, } \\
\text { psychological distress }(p \\
<0.001) \text {, and pain-related } \\
\text { dysfunction }(p<0.001) \text {. } \\
\text { The impact of smoking is } \\
\text { apparently more pronounced } \\
\text { in the pain intensity variable } \\
\text { (adjusted } \mathrm{R}^{2}=0.103 \text { ) with } \\
\text { relatively small effect sizes } \\
\text { in the SCL-90R and MPI } \\
\text { measures. }\end{array}$ \\
\hline $\begin{array}{l}\text { Custodio et } \\
\text { al./015/United } \\
\text { Kingdom } \\
\text { /Journal of Oral } \\
\text { \& Facial Pain and } \\
\text { Headache/.76 }\end{array}$ & $\begin{array}{l}\text { Case } \\
\text { Series }\end{array}$ & $\begin{array}{l}529 \text { individuals } \\
\text { aged } 18 \text { to } 84 \text { years } \\
\text { with myofascial } \\
\text { masticatory pain } \\
\text { diagnosis. } \\
\text { Smokers }(n=170) \\
\text { Age: } 35.5 \pm 9.77 \\
\text { Non-smokers }(n= \\
359) \\
\text { Age: } 38.78 \pm 13.62\end{array}$ & $\begin{array}{l}\text { Diagnosis by DC/TMD; } \\
\text { Pittsburgh Sleep Quality } \\
\text { Index (PSQI); } \\
\text { Global Severity Index } \\
\text { (GSI) of the Symptom } \\
\text { Checklist-90 (revised); } \\
\text { Analog Visual Scale } \\
\text { 0-10 (EVA); }\end{array}$ & $\begin{array}{l}\text { Descriptive } \\
\text { statistics; } \\
\text { Test T for } \\
\text { independent } \\
\text { samples; } \\
\text { Chi-square; } \\
\text { Multiple } \\
\text { Linear } \\
\text { Regression; }\end{array}$ & $\begin{array}{l}\text { Smokers showed higher } \\
\text { pain severity }(7.77 \pm 1.91, \\
p<0.01) \text { and greater sleep } \\
\text { interruption (total PSQI }= \\
12.58 \pm 4.48 \text { vs. } 10.58 \pm \\
1.19, p<0.001) ; \\
\text { Smoking was considered a } \\
\text { predictor of sleep disturbance } \\
(\beta=0.009, p<0.01), R^{2}= \\
0.05) .\end{array}$ \\
\hline $\begin{array}{l}\text { Burris et al. /013/ } \\
\text { United States/ } \\
\text { Behavioral } \\
\text { Medicine/.39 }\end{array}$ & $\begin{array}{l}\text { Cross- } \\
\text { sectional }\end{array}$ & $\begin{array}{l}48 \text { women with } \\
\text { orofacial pain and } \\
\text { age above } 18 \text { years } \\
(41.06 \pm 13.9) \\
\text { Diagnosis of muscle } \\
\text { pain } \\
(60.4 \%, n=9) \\
\text { Temporomandibular } \\
\text { pain }(14.6 \% ; n=7) \\
\text { Neuropathic pain } \\
(12.5 \% ; n=6) \\
\text { Other diagnoses } \\
(12.5 \%, n=6) \text {. }\end{array}$ & $\begin{array}{l}\text { Diagnosis by DC/TMD; } \\
\text { Tobacco Use } \\
\text { Questionnaire; } \\
\text { Fagerstrom test for } \\
\text { nicotine deprivation; } \\
\text { Theory of Planned } \\
\text { Behavior Questionnaire } \\
\text { Symptom Checklist-90 } \\
\text { (revised); } \\
\text { Multidimensional Pain } \\
\text { Inventory; } \\
\text { Multidimensional } \\
\text { inventory of fatigue } \\
\text { symptoms (short } \\
\text { version); } \\
\text { Pittsburgh Sleep Quality } \\
\text { Index; }\end{array}$ & $\begin{array}{l}\text { Descriptive } \\
\text { statistics; } \\
\text { Test T for } \\
\text { independent } \\
\text { samples; } \\
\text { Chi-square; } \\
\text { Effect size } \\
\text { (Cohen's d); } \\
\text { Pearson's } \\
\text { Correlation; } \\
\text { Multivariate } \\
\text { Linear } \\
\text { Regression; }\end{array}$ & $\begin{array}{l}\text { There was no statistical } \\
\text { difference in pain duration } \\
\text { between smokers and } \\
\text { nonsmokers. However, } \\
\text { smokers reported less self- } \\
\text { control over pain and ability } \\
\text { to cope with it }(p=0.02) \text {, } \\
\text { greater fatigue }(p<0.01) \text {, } \\
\text { and poorer sleep quality ( } p= \\
0.04) \text {. }\end{array}$ \\
\hline
\end{tabular}




\begin{tabular}{|c|c|c|c|c|c|}
\hline $\begin{array}{l}\text { Sanders et al./012/ } \\
\text { United States/ } \\
\text { Journal Pain/ } \\
\text { Fator: } 4.519\end{array}$ & $\begin{array}{l}\text { Case- } \\
\text { control }\end{array}$ & $\begin{array}{l}133 \text { cases and } 166 \\
\text { controls. } \\
\text { Age: cases }(36.4 \\
\text { years }(\mathrm{Cl}=34.3- \\
38.6), \text { controls }(8.7 \\
\text { years }(\mathrm{Cl}=7.130 .3) \text {. }\end{array}$ & $\begin{array}{l}\text { Diagnosis by DC/TMD; } \\
\text { Regarding the } \\
\text { classification of } \\
\text { smokers and } \\
\text { nonsmokers, they } \\
\text { were asked: "Have you } \\
\text { smoked at least } 100 \\
\text { cigarettes in your entire } \\
\text { life?" } \\
\text { Blood samples were } \\
\text { collected to identify the } \\
\text { level of cytokines in } \\
\text { the blood (IL-1 Ra and } \\
\text { MCP-1); } \\
\text { 10-item Perceived } \\
\text { Stress Scale (PSS); }\end{array}$ & $\begin{array}{l}\text { Binary } \\
\text { logistic } \\
\text { regression } \\
\text { model; } \\
\text { Odds ratios } \\
\text { (OR) with } \\
\text { confidence } \\
\text { interval }(\mathrm{Cl}) \\
\text { was } 95 \% .\end{array}$ & $\begin{array}{l}\text { Compared to non-smokers, } \\
\text { smokers are } 3 \text { times more } \\
\text { likely to present TMD (OR = } \\
3.33,95 \% \mathrm{Cl}=1.33 ; 7.7) \text {. } \\
\text { The perception of anxiety } \\
\text { and depression is associated } \\
\text { with TMD in a dose-response } \\
\text { relationship. } \\
\text { Smokers were always more } \\
\text { likely to have TMD (OR }= \\
4.14,95 \% \mathrm{Cl}: 1.57,11.35) \\
\text { in the } 18-9 \text { age group when } \\
\text { compared to non-smokers, } \\
\text { but with no statistical } \\
\text { significance in the older age } \\
\text { group }(\mathrm{OR}=1.3,95 \% \mathrm{Cl} \text { : } \\
0.55 ; 0.78) \text {. }\end{array}$ \\
\hline $\begin{array}{l}\text { Melis et al./010/ } \\
\text { United States/ } \\
\text { The Journal of } \\
\text { Craniomandibular } \\
\text { \& Sleep Practice/ } \\
\text { Factor: } \mathbf{0 . 8 7 7}\end{array}$ & $\begin{array}{l}\text { Cross- } \\
\text { sectional; } \\
\text { pilot } \\
\text { study }\end{array}$ & $\begin{array}{l}748 \text { individuals, } 521 \\
\text { with TMD: } \\
166 \text { were excluded. } \\
\text { Smokers: } 314 \\
\text { Non-Smoking: } 38\end{array}$ & $\begin{array}{l}\text { Diagnosis by DC/TMD; } \\
\text { The information } \\
\text { collected: TMD } \\
\text { diagnosis, TMD pain } \\
\text { intensity, number of } \\
\text { cigarettes consumed, } \\
\text { number of cigarettes } \\
\text { smoked in one day, age } \\
\text { and gender; } \\
\text { Numerical scale of pain; } \\
\text { The number of } \\
\text { cigarettes smoked in } \\
\text { one day was evaluated } \\
\text { according to the } \\
\text { patient's self-report; }\end{array}$ & $\begin{array}{l}\text { T-student } \\
\text { test; } \\
\text { ANOVA } 3 \times \\
4 \text { test with } \\
\text { post hoc of } \\
\text { Bonferroni } \\
\text { test; } \\
\text { Pearson's } \\
\text { correlation } \\
\text { test; } \\
\text { Chi-square } \\
\text { test; }\end{array}$ & $\begin{array}{l}\text { A statistical difference in } \\
\text { pain intensity between the } \\
\text { smokers and nonsmokers } \\
\text { groups ( } p=0.007 \text { ) and } \\
\text { stratification in mild, } \\
\text { moderate and severe } \\
\text { smokers ( } p=0.005 \text { ) was } \\
\text { found. } \\
\text { A positive correlation was } \\
\text { found between the number of } \\
\text { cigarettes consumed in one } \\
\text { day and the intensity of pain } \\
\text { for the whole sample and for } \\
\text { the women ( } p<0.0001 \text { and } p \\
=0.001) . \text { The same was not } \\
\text { found for a single sample of } \\
\text { men. } \\
\text { There is a significant effect } \\
\text { between pain intensity and } \\
\text { cigarette smoking for the } \\
\text { whole sample and only for } \\
\text { women ( } p=0.003 \text { and } p= \\
0.008 \text { ). } \\
\text { There is no significant } \\
\text { relationship between } \\
\text { cigarette smoking and a } \\
\text { specific diagnosis of } D C / \\
\text { TMD. }\end{array}$ \\
\hline
\end{tabular}




\begin{tabular}{|c|c|c|c|c|c|}
\hline $\begin{array}{l}\text { Weingarten et } \\
\text { al.//009/United } \\
\text { States/Journal of } \\
\text { Pain/4.519/ }\end{array}$ & $\begin{array}{l}\text { Case } \\
\text { series }\end{array}$ & $\begin{array}{l}606 \text { patients with } \\
\text { TMD; } \\
\text { 91(15.1\%) subjects } \\
\text { use tobacco; } \\
\text { 153(5.4\%) reported } \\
\text { having smoked in the } \\
\text { past; } \\
\text { 359(59.5\%) denied } \\
\text { having used tobacco; } \\
\text { 133(89.3\%) stopped } \\
\text { smoking more than } \\
1 \text { year and } 94(63 \%) \\
\text { stopped smoking } \\
\text { more than } 11 \text { years; } \\
\\
\text { Smokers: men: } \\
71(77 \%) ; \text { women: } \\
\text { 1(0.8\%); age: } \\
36(12) ; \text { unilateral } \\
\text { pain: } 40(43.5 \%) ; \\
\text { myofascial pain: } \\
45(48.9 \%) ; \text { bruxism: } \\
\text { 1(0.8\%); } \\
\text { Ex-smokers: males: } \\
\text { 122(79.7\%); women: } \\
31(0.3 \%) ; \text { age: } \\
51(16) ; \text { unilateral } \\
\text { pain: } 69(45.1 \%) ; \\
\text { myofascial pain: } \\
74(48.4 \%) ; \text { bruxism: } \\
3(15 \%) ; \\
\text { Never smokers: } \\
\text { men: } 304(84.9 \%) ; \\
\text { women: } 54(15.1 \%) ; \\
\text { age: } 44(17) ; \text { unilateral } \\
\text { pain: } 170(47.6 \%) ; \\
\text { myofascial pain: } \\
\text { 151(42\%); bruxism: } \\
76(1 \%) ;\end{array}$ & $\begin{array}{l}\text { Diagnosis by DC/TMD; } \\
\text { Basic health } \\
\text { questionnaire, } \\
\text { consisted of } \\
\text { demographic, habits, } \\
\text { including smoking } \\
\text { habits; } \\
\text { Scale for evaluation of } \\
\text { chronic pain; }\end{array}$ & $\begin{array}{l}\text { Analysis of } \\
\text { variance } \\
\text { (continuous } \\
\text { variables); } \\
\text { Chi- } \\
\text { square for } \\
\text { dichotomous } \\
\text { variables; } \\
\text { ANCOVA; } \\
\text { Logistic } \\
\text { regression; }\end{array}$ & 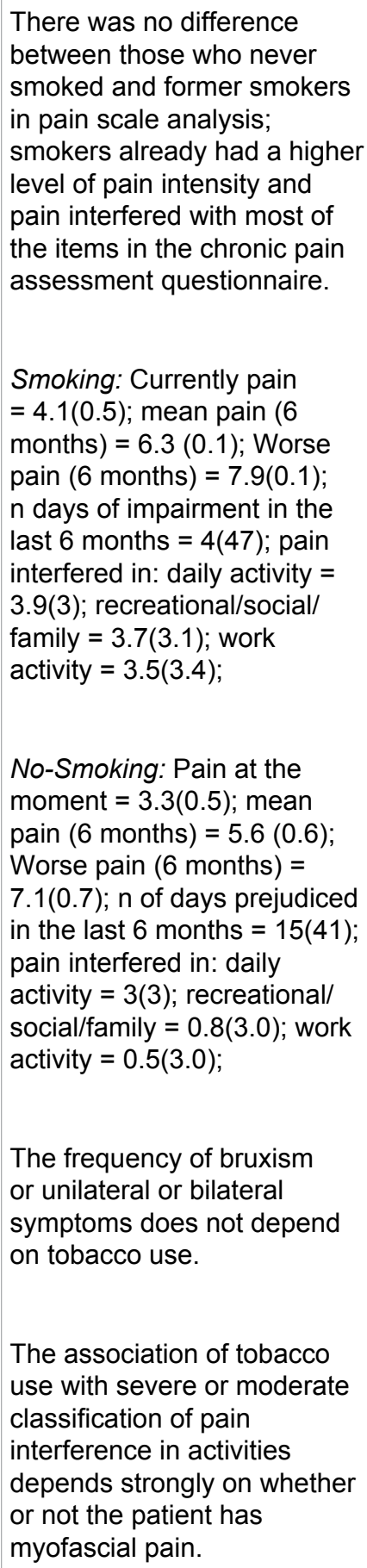 \\
\hline & & & & & $\begin{array}{l}\text { There was no association } \\
\text { between myofascial pain and } \\
\text { self-reported pain. }\end{array}$ \\
\hline
\end{tabular}

DC/TMD: Research Diagnostic Criteria for Temporomandibular Disorders.

qualitative analysis of the observational studies used.

\section{Discussion}

This integrative review aimed to gather the literature data about the repercussions that smoking has on the development/triggering of signs and symptoms of temporomandibular dysfunction (TMD). Some important data have been verified, among them, that smokers have a 3-fold higher risk of presenting TMD $(3.33(\mathrm{Cl}=$ 1.33-7.7) in relation to nonsmokers, especially in the 18 to 29 age group, and the more advanced age the low- er this risk. In addition, the perception of pain intensity was divergent among the groups of smokers and nonsmokers, with worsening of the perception of pain proportional to the number of cigarettes consumed in the day, especially in women. There was a difference in the orofacial pain intensity between smokers and nonsmokers, however when compared nonsmokers to ex-smokers, this difference did not occur.

The explanation for the decrease in pain threshold is physiological, through alteration in inflammatory pathways or allergic processes. Smoking increases the 
production of proinflammatory cytokines and inhibits anti-inflammatory cytokines, also increasing allergen sensitization and respiratory epithelial permeability $[7,14]$. When evaluated the intensity of pain in these studies, smokers had lower tolerance and worse selfcontrol over pain $[15,16]$.

The active ingredient of tobacco that alters the perception of pain is not yet fully understood, but it is generally assumed that nicotine is the first substance to modify pain perception [10]. Still, nicotine has analgesic properties, so chronic exposure to tobacco alters the regulation mechanism of pain control, and when there is nicotine depression in the body, there is an increased sensitivity to pain by evoked stimulus. In addition, this exposure may induce a biological state that produces hyperalgesia and dependence similar to chronic exposure of opioids, and may also affect the mechanisms involved in sleep [15].

Nicotine acts in the central nervous system releasing neurotransmitters that are involved during wakefulness, explaining the sleep disturbances found in smokers, especially the fragmentation and consequently poorer sleep quality [17]. When the effects of smoking on TMD patients were analyzed, there was a greater interruption and worse quality of sleep. Furthermore, smoking was considered a predictor of sleep disturbance $[15,18]$.

Smokers were shown to have worse self-control of pain and more severe fatigue. These factors cause psychological distress as well as worsen the anxiety and depression symptoms common in individuals with TMD. In addition to the association of smoking with high levels of anxiety and depression, one study has shown that pain-related anxiety is one of the factors that make abstinence difficult, suggesting that smoking is one of the causes of cigarette addiction [19].

Among the causes of TMD is joint overload, often caused by parafunctional habits, resulting in a change in the cartilaginous metabolism, in which the degradation of the cartilaginous matrix exceeds the production. In addition to the histopathological mechanisms, biomechanical alterations and increased muscular tension are also involved in the process, especially when related to pain due to joint dysfunction $[20,21]$.

However, no study analyzed the importance of the biomechanical mechanisms involved in smoking, which in turn can directly or indirectly influence the signs and symptoms of TMD. One hypothesis raised in the literature is that continuous cigarette use may affect orofacial muscle and joint structures and may worsen symptoms of TMD pain intensity, and this is likely to influence muscle metabolism, disc degeneration and even in bruxism. This hypothesis has been suggested because it is already established that smoking is associated with the occurrence of low back pain, presence of disc degeneration and disc herniation, and worsening the oc- currence of bruxism $[8,22]$.

The development of this review was important to elucidate the clinical and important consequences of smoking in adult patients with orofacial pain. However, we assume that the inclusion of the Snowball strategy to rescue new research conducted in the same segment, as well as other studies not yet published (Gray literature) [23]. There is a need for further studies in different countries and to assess the risk of developing temporomandibular dysfunction or orofacial pain when exposed to smoking, since the vast majority of studies are cross-sectional studies.

\section{Conclusion}

It is concluded that smoking may affect the painful perception of TMD patients, besides influencing comorbid aspects such as fatigue worsening, pain control, sleep quality and psychological distress. Furthermore, it is not possible to conclude that there is an association between pain intensity and biomechanical aspects of smoking due to a lack of studies in this area with good methodological quality.

\section{References}

1. Shephard MK, Macgregor EA, Zakrzewska JM (2014) Orofacial pain: A guide for the headache physician. Headache 54: 22-39.

2. Bevilaqua-Grossi D, Chaves TC, De Oliveira AS, MonteiroPedro V (2006) Anamnestic index severity and signs and symptoms of TMD. Cranio 24: 112-118.

3. Pedroni CR, De Oliveira AS, Guaratini MI (2003) Prevalence study of signs and symptoms of temporomandibular disorders in university students. Journal of Oral Rehabilitation 30: 283-289.

4. Gustin SM, Wilcox SL, Peck CC, Murray GM, Henderson LA (2011) Similarity of suffering: Equivalence of psychological and psychosocial factors in neuropathic and non-neuropathic orofacial pain patients. Pain 152: 825-832.

5. Shaffer SM, Brismée J-M, Sizer PS, Courtney CA (2014) Temporomandibular disorders. Part 2: conservative management. Journal of Manual \& Manipulative Therapy 22: 13-23.

6. Turner JA, Dworkin SF, Mancl L, Huggins KH, Truelove EL (2001) The roles of beliefs, catastrophizing, and coping in the functioning of patients with temporomandibular disorders. Pain 92: 41-51.

7. Silvestri M, Franchi S, Pistorio A, Petecchia L, Rusconi F (2015) Smoke exposure, wheezing, and asthma development: A systematic review and meta-analysis in unselected birth cohorts. Pediatric Pulmonology 50: 353362.

8. Melis M, Lobo SL, Ceneviz C, Ruparelia UN, Zawawi $\mathrm{KH}$, et al. (2010) Effect of cigarette smoking on pain intensity of TMD patients: A pilot study. Cranio - Journal of Craniomandibular Practice 28: 187-192.

9. Sanders AE, Maixner W, Nackley AG, Diatchenko L, By $\mathrm{K}$, et al. (2012) Excess risk of temporomandibular disorder associated with cigarette smoking in young adults. Journal of Pain 13: 21-31. 
10. Shi Y, Weingarten TN, Mantilla CB, Hooten WM, Warner DO (2010) Smoking and pain : Pathophysiology and clinical implications. Anesthesiology 113: 977-992.

11. Tacconelli E (2010) Systematic reviews: CRD's guidance for undertaking reviews in health care. The Lancet Infectious Diseases 10: 226.

12. Santos C, Pimenta C, Nobre M (2007) A estratégia PICO para a construção da pergunta de pesquisa e busca de evidências. Rev Latino-Am Enfermagem 15: 3.

13. Liberati A, Altman DG, Tetzlaff J, Mulrow C, Gøtzsche PC, et al. (2009) The PRISMA statement for reporting systematic reviews and meta-analyses of studies that evaluate health care interventions: explanation and elaboration. Journal of Clinical Epidemiology 62: e1-e34.

14. Katyayan P, Katyayan M (2017) Effect of smoking status and nicotine dependence on pain intensity and outcome of treatment in Indian patients with temporomandibular disorders: A longitudinal cohort study. The Journal of Indian Prosthodontic Society 17: 156-166.

15. Custodio L, Carlson CR, Upton B, Okeson JP, Harrison $A L$, et al. (2015) The Impact of Cigarette Smoking on Sleep Quality of Patients with Masticatory Myofascial Pain. Journal of Oral \& Facial Pain and Headache 29: 15-23.

16. Weber T, Boggero IA, Carlson CR, Bertoli E, Okeson JP, et al. (2016) Smoking and Posttraumatic Stress Disorder Symptomatology in Orofacial Pain. Journal of Dental Research 95: 2016.
17. Sharma R, Lodhi S, Sahota P, Thakkar MM (2015) Nicotine administration in the wake-promoting basal forebrain attenuates sleep-promoting effects of alcohol. Journal of Neurochemistry 135: 323-331.

18. Burris JL, Perez C, Evans DR, Carlson CR (2013) A preliminary study of cigarette smoking in female orofacial pain patients. Behavioral Medicine 39: 73-79.

19. de Leeuw R, Eisenlohr-Moul T, Bertrand P (2013) The Association of Smoking Status with Sleep Disturbance, Psychological Functioning, and Pain Severity in Patients with Temporomandibular Disorders. Journal of Orofacial Pain 27: 32-41.

20. Chaves TC, dos Santos Aguiar A, Felicio LR, Greghi SM, Hallak Regalo SC, et al. (2017) Electromyographic ratio of masseter and anterior temporalis muscles in children with and without temporomandibular disorders. International Journal of Pediatric Otorhinolaryngology 97: 35-41.

21. Israel HA (2016) Internal Derangement of the Temporomandibular Joint: New Perspectives on an Old Problem. Oral and Maxillofacial Surgery Clinics of North America 28: 313-333.

22. Molina OF, Dos Santos J, Mazzetto M, Nelson S, Nowlin T, et al. (2001) Oral Jaw Behaviors in TMD and Bruxism: A Comparison Study by Severity of Bruxism. Cranio 19: 114-122.

23. Van Weert JCM, Van Munster BC, Sanders R, Spijker R, Hooft L, et al. (2016) Decision aids to help older people make health decisions: A systematic review and meta-analysis. BMC Medical Informatics and Decision Making 16: 45. 